\title{
The EU Black List of Third-Country Jurisdictions
}

\section{THREE-STEP PROCESS: SCOREBOARD, SCREENING AND LISTING}

Jurisdiction $X$ 'does not apply any automatic exchange of financial information, has not signed and ratified, including through the jurisdiction they are dependent on, the OECD Multilateral Convention on Mutual Administrative Assistance as amended, does not apply the BEPS minimum standards and did not commit to addressing these issues by 31 December 2018'. This is one standard justification for including some third-country jurisdictions on the EU list of non-cooperative jurisdictions for tax purposes as approved on 5 December 2017, in the form of Council conclusions.

The risk indicators of (1) transparency and exchange of information, (2) preferential tax regimes and (3) no corporate income tax or zero (or nearly zero) income tax rate are applied by the Code of Conduct Group and the Member States to the selected 160 third-country jurisdictions to exclude or include them on the black list. (These risk indicators were also used to decide on the jurisdictions to screen.)

Seventeen jurisdictions were initially included on the list, namely American Samoa, Bahrain, Barbados, Grenada, Guam, Korea (Rep.), Macao, Marshall Islands, Mongolia, Namibia, Palau, Panama, Saint Lucia, Samoa, Trinidad and Tobago, Tunisia, and United Arab Emirates.

An additional forty-seven jurisdictions, mentioned under Annex II of the Council conclusions of 5 December 2017 (a so-called grey list), are expected to upgrade their 'tax good governance principles'. Depending on the particular case, they have publicly committed to implement automatic exchange of information, to conclude a relevant network of agreements covering EU Member States, to implement Base Erosion and Profit Shifting Project (BEPS) minimum standards, to abolish their harmful tax regimes and tax regimes facilitating offshore structures that attract profits without real economic activity and/or to simply become a member of the Global Forum. ${ }^{1}$
On 23 January 2018, eight jurisdictions have been delisted, following commitments made at a high political level to remedy EU concerns, and moved to a separate category of jurisdictions subject to close monitoring.

Those jurisdictions are: Barbados, Grenada, the Republic of Korea, Macao SAR, Mongolia, Panama, Tunisia and the United Arab Emirates. ${ }^{2}$

This is the recent outcome of a procedure that started in 2016, based on a three-step process and based on objective criteria and transparency: a scoreboard, screening and listing. There are reasons why most players involved are satisfied with the outcome, including because the OECD has not yet managed to agree on which jurisdictions should be included on a list. The EU has once again moved past the OECD to set a standard. However, it is relatively frustrating that it is necessary to return to black lists, after the OECD announced in 2009 that the era of tax havens had come to an end. Referring to its report 'Tax Co-operation 2009: Towards a Level Playing Field', the OECD stated as follows:

The (2009) report highlights the progress made up to 31 July 2009:

- All OECD countries now accept Article 26 (Exchange of Information) of the OECD Model Tax Convention, as updated in 2005, following the withdrawal in March 2009 by Austria, Belgium, Luxembourg and Switzerland of their reservations to Article 26.

- Hong Kong, China and Macao, China endorsed the standards at the 2005 Global Forum meeting in Melbourne and have now put forward legislation to enable them to implement the standards.

- Singapore endorsed the standards on 10 February 2009 and proposed relevant legislation in June 2009 intended to comply with the internationally agreed tax standard.

- More than 75 tax information exchange agreements (TIEAs) based on the Global Forum's model have been signed since the beginning of 2008 .

\section{Notes}

Annex II to the Council conclusions of 5 Dec. 2017.

http://www2.consilium.europa.eu/en/press/press-releases/2018/01/23/taxation-eight-jurisdictions-removed-from-eu-list/ (accessed on 21 Feb. 2018). 
- Andorra, Liechtenstein and Monaco - identified by the OECD in 2002 as un-cooperative tax havens - have endorsed the OECD standards and indicated their willingness to change their domestic legislation and to enter into agreements for the exchange of information for tax purposes.

- Niue, which was identified as a tax haven by the OECD in 2000, reports that it has now eliminated its offshore sector and dissolved all of its international business companies, trusts, partnerships or other offshore entities.

- Brunei, Costa Rica, Guatemala, Malaysia, the Philippines and Uruguay have all endorsed the OECD's standards of transparency and exchange of information and agreed to implement them.

These developments mean that all countries surveyed by the Global Forum are now committed to the standard.

Most importantly the report shows that many other significant developments are underway as countries work to implement the OECD standards. In particular, virtually all countries are moving to eliminate strict bank secrecy for tax purposes. ${ }^{3}$

On a positive note, the EU move can be seen as one step further in exerting pressure on jurisdictions that are reluctant to become cooperative.

\section{THE CRITERIA FOR SCREENING JURISDICTIONS}

The criteria set in the Annex to the Council conclusions of 8 November 2016 relate not only to tax transparency, but also to fair taxation and implementation of anti-BEPS measures. They are used as EU international tax standards to be applied by all jurisdictions, in a dynamic process (initial $v$. future criterion) that cross-checks a legislative process to effectively implement the Common Reporting Standard and first exchanges in 2018. Part of this dynamic is revealed by a less demanding initial criterion in comparison to the future criterion. For example regarding the OECD automatic exchange of information, the jurisdictions must have committed and started the legislative process (initial criterion) and should possess as from 2018 at least a 'largely compliant' rating by the Global Forum, in respect of both automatic exchange of information and exchange of information upon request. ${ }^{4} \mathrm{~A}$ third criterion on transparency requires that all EU Member States benefit from exchange of information, either by ratification of the OECD Multilateral Convention on Mutual Administrative Assistance in Tax Matters, or by a network of exchange agreements that cover both automatic exchange of information and exchange of information upon request and all EU Member States.

Until 30 June 2019, two out of the three afore-mentioned criteria for tax transparency must be fulfilled in order for a third-country jurisdiction to be regarded as compliant, as long as it was not rated 'non-compliant' by the Global Forum. It was also foreseen to include beneficial ownership information as a fourth criterion for screening, due to the initiative for future global exchange of beneficial ownership information.

It is questionable whether all the jurisdictions now included on the black list and all those others that are committed to improving their standards will accomplish the necessary taxpayer guarantees in order to implement the international standards. Stability factors, mentioned below, such as corruption and regulatory quality, are an example of shortcomings and that have been included in the score analysis by the Commission (see, for example, the scores for Armenia, Fiji, Peru and Swaziland). ${ }^{5}$

There are two criteria that a jurisdiction must fulfil in order to be considered compliant on fair taxation ${ }^{6}$ : it must not have preferential tax measures that could be regarded as harmful under the criteria in the Code of Conduct for business taxation, ${ }^{7}$ and it must not 'facilitate offshore structures or arrangements aimed at attracting profits which do not reflect economic activity in the jurisdiction'. The vagueness of the latter criterion is an interesting link to the Base Erosion and Profit Shifting project, but gives rise to a discretionary assessment by the Member States and the Code of Conduct Group leading the screening and followup processes. The latter criterion also introduces pressure on the EU Member States as regards whether they themselves comply with the fair taxation criteria.

The implementation of anti-BEPS measures requires that a jurisdiction commit, by the end of 2017, to the agreed OECD anti-BEPS minimum standards and the consistent application thereof (and, in future, the jurisdiction must receive a positive assessment as regards the effective implementation of those standards). ${ }^{9}$

\section{Notes}

OECD, OECD Assessment Shows Bank Secrecy as a Shield for Tax Evaders Coming to an End (31 Aug. 2009), http://www.oecd.org/ctp/harmful/oecdassessmentshowsbanksecre cyasashieldfortaxevaderscomingtoanend.htm (accessed 10 Jan. 2018).

Annex to the Council Conclusions of 8 Nov. 2016, 14166/16, FISC 187, ECOFIN 1014, at 4-5.

5 European Commission, Directorate-General for Trade, Negotiations and Agreements, First Steps Towards a New EU List of Third Country Jurisdictions: Scoreboard, https://ec.europa. eu/taxation_customs/sites/taxation/files/2016-09-15_scoreboard-indicators.pdf (accessed 10 Jan. 2018).

Annex to the Council conclusions of 8 Nov. 2016, at 6.

Resolution of the Council and the Representatives of the Governments of the Member States meeting within the Council of 1 Dec. 1997 on a Code of Conduct for Business Taxation, OJ C 2, 6 Jan. 1998, at 2.

8 Annex to the Council conclusions of 8 Nov. 2016, at 6 .

9 Annex to the Council conclusions of 8 Nov. 2016, at 7 . 


\section{THE PROCEDURE}

The process was endorsed by the Member States at the May 2016 ECOFIN meeting, and on 14 September 2016 the European Commission completed the first step: a scoreboard of all third countries and jurisdictions for tax purposes - based on objective economic, financial, stability and tax good governance indicators - to help determine the potential risk level of a jurisdiction in facilitating tax avoidance. The aforementioned indicators are meant to be an objective and robust data source. ${ }^{10}$

The Commission started by collecting data available for all countries and jurisdictions, but excluding the 28 Member States and the territories considered to be part of them. Categories of third-country jurisdictions were featured in five separate groups: those that rank high in all selection indicators; those that already have a transparency agreement with the EU (Andorra, Liechtenstein, Monaco, San Marino and Switzerland); third-country jurisdictions that do not rank high in at least one of the selection indicators; third-country jurisdictions with no economic data; and the 48 least-developed countries identified by the United Nations. Group 1 became the target for the subsequent steps.

The selection indicators refer to the strength of economic ties with the EU (trade data, affiliates controlled by EU residents and bilateral flows of foreign direct investment); financial activity meant to determine the balance between the level of financial services exports and the connection or disconnection between the financial activity and the real economy; and stability factors such as corruption and regulatory quality.

The scoreboard was the first basis for Member States in the Code of Conduct Group to decide which third-country jurisdictions warranted more in-depth screening.

As part of Step 2, 160 third-country jurisdictions were screened by the EU. The EU list (Step 3) was then made public in the afore-mentioned Council conclusions of 5 December 2017.

\section{Final REMARKS}

Defensive measures are recommended in Annex III of the Council conclusions of 5 December 2017 and are divided into defensive measures in the non-tax area and in the tax area. The former are related to the European Fund for Sustainable Development. If they mean that the EU may not grant aid to less developed jurisdictions if the latter do not comply with the screening criteria, such defensive measures would likely provoke a snowball effect by making it virtually impossible for those less developed jurisdictions to become (largely) compliant.

Defensive measures in the tax area are less controversial. They can consist of reinforced monitoring of certain transactions; increased audit risks for taxpayers investing or using structures or arrangements involving the blacklisted jurisdictions; and several anti-BEPS measures.

Because the EU black list, the 'grey' list and the defensive measures are included in Council conclusions and not in a binding EU law instrument, Member States are still free to adopt them or not and to keep their own black lists (if they have a black list) which can lead to circumvention schemes. The effect of this soft law procedure in the EU national parliaments and governments remains be seen.

Some of the major achievements in the overall screening process that led to the black list and the 'grey', include its transparency and the effort to lay down objective criteria in spite of some discretion in the assessment of those criteria. Transparency in the screening process started with the publication of the scoreboard, which permits confrontation with the final outcome. But transparency is also present in the detailed Council conclusions of 8 November 2016 and 5 December 2017, related to criteria, jurisdictions involved and schedule. This is indeed a best practice, to be followed in future international screening processes. However worldwide credibility of the EU black list will very much depend on the implementation of the fair taxation criterion by the EU Member States themselves.

Ana Paula Dourado General-Editor

Member for the EU Platform on Tax Good Governance 